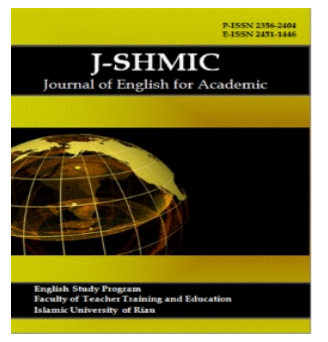

J-SHMIC : Journal of English for Academic

ISSN : 2641-1446 (Online) ISSN :2356-2404 (Print)

Homepage: https://journal.uir.ac.id/index.php/jshmic

Vol 9, No 1, February 2022

\title{
A Study of Perception of the Importance of English Language Skills among Indonesian Hotel Employees
}

\author{
Stefanus Angga B. Prima ${ }^{1}$, Dang Arif Hartono ${ }^{2}$ and Budi Riyanto ${ }^{3}$ \\ Universitas Agung Podomoro ${ }^{1,2,3}$ \\ stefanus.angga@podomorouniversity.ac.id ${ }^{l}$; dang.arif@podomorouniversity.ac.id ${ }^{2}$; \\ budi.riyanto@podomorouniversity.ac.id ${ }^{3}$
}

\begin{abstract}
Indonesia's economy is increasingly dependent on tourism industry, so the quality of the service given by the employees of the industry plays a crucial role. English language skills have long been understood as an important for this quality service, but its importance varies as English is spoken as a lingua franca among the employees. Therefore, conducting English classes in the context of ESP (English as a Specific Purpose) in hospitality and tourism requires thorough needs analysis that serves the needs all stakeholders, especially employees. Both from Indonesia and abroad, the previous studies mostly investigate the perceptions of students of hospitality or tourism major, so the perceptions of Indonesian hotel employees from different hotel stars are rarely investigated. This study is aimed at investigating Indonesian hotel employees' $(n=77)$ perceptions towards various aspects of English skills of different hotel stars. Four Hypotheses were tested using Kruskal-Wallis non-parametric test. Our study demonstrates that no statistical differences were found on the 15-item questionnaire responses based on gender, current job level, hotel stars, and current job departments. Despite that, the results showed that listening and speaking skills are perceived as the most important, while spoken grammar is considered as the least important.
\end{abstract}

\begin{abstract}
ABSTRAK
Ekonomi Indonesia semakin bergantung pada industry pariwisata, sehingga kualitas pelayanan menjadi semakin penting. Kemampuan Bahasa Inggris sudah sejak lama dianggap sebagai faktor penentu kualitas pelayanan, tetapi banyak pendapat berbeda tentang seberapa pentingnya kemampuan ini karena Bahasa Inggris dipakai sebagai lingua franca oleh karyawan industry pariwisata. Maka dari itu, pengajaran Bahasa Inggris untuk perhotelan dan pariwisata membutuhkan analisis kebutuhan yang menyeluruh sehingga dapat memuaskan semua pihak, terutama karyawan. Sebagian besar penelitian di Indonesia dan luar negeri hanya menyelidiki persepsi mahasiswa perhotelan dan pariwisata, sedangkan persepsi karyawan
\end{abstract}

KATA KUNCI

karyawan; hotel; persepsi 
Stefanus Angga B. Prima ${ }^{1}$, Dang Arif Hartono ${ }^{2}$ and Budi Riyanto ${ }^{3}$

J-SHMIC: Journal of English for Academic

Vol 9, No 1, February 2022

hotel jarang sekali diteliti. Penelitian ini bertujuan untuk mengkaji persepsi karyawan hotel dari hotel berbintang di Indonesia $(n=77)$ terhadap berbagai aspek dalam kemampuan berbahasa Inggris. Terdapat empat Hipotesis yang diuji dan tidak ditemukan adanya perbedaan statistik yang signifikan dari hasil kuesioner yang dihimpun berdasarkan jenis kelamin, tingkat pekerjaan sekarang, bintang hotel, dan departemen tempat bekerja saat ini. Meskipun demikian, ditemukan bahwa sebagian besar karyawan hotel beranggapan kemampuan mendengarkan dan berbicara merupakan kemampuan terpenting, sedangkan tata bahasa ketika bicara sebagai yang paling dianggap tidak penting.

\section{INTRODUCTION}

In 2019, Indonesian Ministry of Tourism and Creative Industry (Kemenparekraf, 2021) recorded that the foreign tourist's arrival in Indonesia reached its peak with more than 16 million arrivals from all Indonesian international airports. However, the COVID-19 pandemic swept all over the world in March 2020, which then dwindled the number to just over four million arrivals. Despite this condition, tourism remains one of the leading sectors of Indonesian economy, which then affects the training aspect of this industry.

In hospitality and tourism sectors, the English language skill is commonly regarded as important in Indonesia, a country in which English is spoken as a foreign language. With the specific needs that are different from general English, the English courses in these sectors belong to English for Specific Purposes (ESP). In ESP, teachers or course designers will need to find which 'discourse community' the students will join, so the curriculum and material will suit the learners' needs and how they utilize English within their work (Terauchi, Noguchi, \& Tajino, 2019). The aforementioned 'discourse community' may vary depending on the nature of learners' professional environment. For five-star hotels, English language skills requirements during employee's selection process are necessary as the employees deal with foreigners in daily basis.

In their phenomenal book about English for Specific Purposes, Hutchinson and Waters (1987) explain that the main difference between ESP and General English lies in the awareness of its learners. In ESP, learners are aware that they need English language skill to accomplish their professional duties. Therefore, it is not only because the specific language features that are specific to their needs, but the awareness of the learners.

In hospitality and tourism, English serves as the lingua franca as most of its speakers are non-native (Zahedpisheh, B Abu bakar, \& Saffari, 2017). Learners are aware of this, and so their expectations and needs about the use of English language communicative skills may vary. Furthermore, in a teaching environment like this, it is important to develop a teaching curricula that suits the learning style and language use of the students attending the class (McKay, 2018). 
In this sense, the best way to get what the learners want to learn is by conducting needs analysis. During needs analysis, course and material designers can utilize unstructured interviews with people working in the industry (Long, 2005). Additionally, he suggests that questionnaire including random participants of the total population of the industry can be used to gather information necessary to develop well-suited curriculum and material.

According to Dudley-Evans and St. John (1998), English for tourism belongs to the category of EOP (English for Occupational Purposes), which is then categorized further into English for Professional Purpose. In general, within this specific purpose for hospitality and tourism, all four communicative language skills in English (listening, speaking, reading, and writing) are regarded as important (Prachanant, 2012). However, further research findings show that learners of English language classes in hospitality and tourism consider speaking and listening as vital skills to learn due to the communicative nature of the work (Ghany \& Latif, 2012; Kaharuddin, Hikmawati, \& Burhanuddin, 2019; Putri, Kher, \& Rani, 2018). Similarly, in other Asian countries, such as in Pakistan (Yasmin, Sarkar, \& Sohail, 2016) and Japan (Bury \& Oka, 2017), it is concluded that listening and speaking are considered as important English language skills compared to reading and writing in the field of tourism and hospitality.

The participants of the previous studies were students and mostly did not distinguish the needs of English language skills between departments and the hotel star level. Therefore, the current study attempted to adapt the study conducted by Bury and Oka (2017) to fill in the gap by examining the perceptions of the other stakeholders, which is the hotel employees. To do that, the study attempted to test the four following hypotheses:

(1) H0: There will be no significant difference between male and female employees in the industry's perceptions of the importance of various aspects of English in the tourism and hospitality industry.

H1: There will be a significant difference between male and female employees in the industry's perceptions of the importance of various aspects of English in the tourism and hospitality industry.

(2) H0: There will be no significant difference between employees of different job levels in the industry's perceptions of the importance of various aspects of English in the tourism and hospitality industry.

H1: There will be a significant difference between employees of different job levels in the industry's perceptions of the importance of various aspects of English in the tourism and hospitality industry.

(3) H0: There will be no significant difference between employees of different hotel stars in the industry's perceptions of the importance of various aspects of English in the tourism and hospitality industry.

H1: There will be a significant difference between employees of different hotel stars in the industry's perceptions of the importance of various aspects of English in the tourism and hospitality industry. 
(4) H0: There will be no significant difference between employees of different departments in the industry's perceptions of the importance of various aspects of English in the tourism and hospitality industry.

H1: There will be a significant difference between employees of different departments in the industry's perceptions of the importance of various aspects of English in the tourism and hospitality industry.

\section{METHOD}

This research was carried out using quantitative method. Using quantitative methods in second or foreign language research brings several advantages. One advantage is that it improves precision and enhances the strength of statistics calculation of the research (Brown, 2015).

To investigate the perception of hotel employees of English language skill, an online 15item questionnaire was distributed using Survey Monkey in mid-2020. Among those 15-item questionnaires, nine items asked about the participants' perceptions of English language skill of various aspects, while the other six were demographic questions. The questionnaire items were five-scale Likert scale which were developed based on the study conducted by Bury and Oka (2017), which investigated the perceptions about English language skills of undergraduate students studying tourism in Japan.

Some adaptations from the original questionnaire included two questionnaire items (item 6 and 7) which specifically asked about the importance of written and spoken grammar respectively. This modification is based on the idea that written grammar is more rigid than spoken grammar (Cao Thanh, 2015). Additionally, due to its nature as lingua franca, English that is spoken among Indonesian hoteliers may be different from that of native speakers' and when appropriate, hotel employees may need to master both 'local and more international varieties' of English (McKay, 2018).

The participants $(n=77)$ of this study were selected by convenient sampling. Hotel employees working in Jakarta and Bali of various levels and departments agreed to take part in this survey after contacted via email. All participants participated anonymously, and the hotel brands were not mentioned to keep confidentiality. Among the participants, 60 were working at five-star hotels in Jakarta or Bali, and the rest were

The results of the questionnaire were imported into CSV files, and then were analyzed using SPSS. Reliability Statistics of Cronbach's Alpha Based on Standardized Items resulted in 0.718 , which was categorized as high reliability index. Additionally, after conducting After Kolmogorov-Smirnov as well as kurtosis and skewness analysis, it was concluded that the data was not normally distributed. Therefore, non-parametric Independent Samples Kruskal-Wallis Test with an alpha level of 0.05 was utilized to test the hypotheses and the confidence interval is $95 \%$.

\section{FINDINGS}

Demographics, departments, current working level, and hotel-stars 
Table 1: Demographics, departments, current working level, and hotel-stars.

\begin{tabular}{|c|c|c|c|c|c|c|c|c|c|}
\hline & \multicolumn{2}{|c|}{ Gender } & \multicolumn{7}{|c|}{ Current Department } \\
\hline & Male & Female & $\begin{array}{c}\mathrm{F} \& \mathrm{~B} \\
\text { Production }\end{array}$ & $\begin{array}{c}\text { F\&B } \\
\text { Service }\end{array}$ & $\begin{array}{l}\text { Front } \\
\text { Office }\end{array}$ & $\begin{array}{c}\text { House } \\
\text { Keeping }\end{array}$ & $\begin{array}{c}\text { Human } \\
\text { Resources }\end{array}$ & $\begin{array}{l}\text { Sales and } \\
\text { Marketing }\end{array}$ & Others \\
\hline $\mathrm{N}$ & 50 & 27 & 13 & 15 & 7 & 6 & 29 & 2 & 5 \\
\hline$\%$ & 64.9 & 35.1 & 16.9 & 19.5 & 9.1 & 7.8 & 37.7 & 2.6 & 6.5 \\
\hline
\end{tabular}

Table 1 shows that most of participants were male (64.9\%), working in human resources department (37.7\%) and having the managerial level at the time they took part in the survey. Some others were in Food and Beverage Service (19.5\%) and Food and Beverage Production $(16.9 \%)$ and those in 'others' were working in engineering and security departments $(6.5 \%)$ at the time they filled in the survey.

Table 2: Participants' current working level, and hotel-stars.

\begin{tabular}{|c|c|c|c|c|c|}
\hline & \multicolumn{3}{|c|}{ Current Level } & \multicolumn{2}{c|}{ Hotel Stars } \\
\cline { 2 - 6 } & Entry & Supervisor & Managerial & Five Stars & Non-five stars \\
\hline $\mathrm{N}$ & 26 & 14 & 37 & 60 & 17 \\
$\%$ & 33.8 & 18.2 & 48.1 & 77.9 & 22.1 \\
\hline
\end{tabular}

Furthermore, Table 2 indicates that most participants were at managerial level $(48.1 \%)$ during the time they took part in the questionnaire and mostly working in five-star hotels (77.9\%). As seen in Table 3, regarding their education level and age, most participants were of Diploma III - associate degree in hospitality or tourism with three-year diploma - $(33.8 \%)$ and high school graduates $(27.3 \%)$ and are between 36 to 45 years old $(29.9 \%)$ with the smallest percentage were those between 18 to 25 years old $(6.5 \%)$.

Table 3: Participants' education level and age

\begin{tabular}{|c|c|c|c|c|c|c|c|c|c|}
\hline & \multicolumn{3}{|c|}{ Education Level } & \multicolumn{3}{c|}{ Age } \\
\cline { 2 - 11 } & Bachelor's & Master's & Diploma III & Diploma IV & $\begin{array}{c}\text { High } \\
\text { /Vocational } \\
\text { School }\end{array}$ & $18-25$ & $26-35$ & $36-45$ & $45>$ \\
\hline $\mathrm{N}$ & 19 & 8 & 26 & 3 & 21 & 5 & 23 & 26 & 23 \\
$\%$ & 24.7 & 10.4 & 33.8 & 3.9 & 27.3 & 6.5 & 29.9 & 33.8 & 29.9 \\
\hline
\end{tabular}

Participants' overall response to the questionnaire

Table 4: Perceived importance of English language skills.

\begin{tabular}{|c|c|c|c|c|c|c|c|}
\hline & \multicolumn{7}{|c|}{ English language skills } \\
\cline { 2 - 7 } & $\begin{array}{c}1 \\
\text { Listening }\end{array}$ & $\begin{array}{c}2 \\
\text { Speaking }\end{array}$ & $\begin{array}{c}3 \\
\text { Reading }\end{array}$ & $\begin{array}{c}4 \\
\text { Writing }\end{array}$ & $\begin{array}{c}5 \\
\text { Vocabulary }\end{array}$ & $\begin{array}{c}6 \\
\text { Grammar in } \\
\text { Writing }\end{array}$ & $\begin{array}{c}\text { Grammar in } \\
\text { Speaking }\end{array}$ \\
\hline Mean & 4.88 & 4.82 & 4.74 & 4.74 & 4.75 & 4.62 & 4.36 \\
SD & 0.323 & 0.388 & 0.441 & 0.441 & 0.463 & 0.539 & 0.826 \\
\hline
\end{tabular}

The results of the survey as shown in Table 4 indicates that hotel employees in the study perceive that all skills as important since the means of all English language skills are above four, which indicates high degree of 'agree' and 'strongly agree' in the Likert scale. However, if looked more closely, among the English language skills, listening receives the highest perceived importance $(M=4.88, \mathrm{SD}=0.32)$, followed by speaking $(M=4.82, \mathrm{SD}=0.388)$. 
Stefanus Angga B. Primal ${ }^{1}$, Dang Arif Hartono ${ }^{2}$ and Budi Riyanto ${ }^{3}$

J-SHMIC: Journal of English for Academic

Vol 9, No 1, February 2022

On the other hands, grammar in speaking has the lowest perceived importance $(M=4.36$, SD $=0.826)$, and the second lowest is grammar in writing $(M=4.62, \mathrm{SD}=0.539)$.

The responses to other factors (Item 8 and 9) contributing to English language skills in the employees' professional lives are shown in Table 5.

Table 5: Perceived attitudes to other factors.

\begin{tabular}{|c|c|c|}
\hline \multirow{2}{*}{} & \multicolumn{2}{|c|}{ Other factors } \\
\cline { 2 - 3 } & 8 & 9 \\
& $\begin{array}{c}\text { It will be difficult to get hired in hospitality } \\
\text { industry if you can't speak English. }\end{array}$ & $\begin{array}{c}\text { It will be difficult to get promoted in hospitality } \\
\text { industry if you cannot speak English. }\end{array}$ \\
\hline Mean & 4.10 & 4.23 \\
SD & 1.059 & 0.944 \\
\hline
\end{tabular}

Additionally, Table 5 shows that most employees agree that the chance to get hired depends on the ability to speak English $(M=4.10, \mathrm{SD}=1.059)$ and it will be difficult to get promotion in the job if they cannot speak English $(M=4.23, \mathrm{SD}=0.944)$.

Table 6. Item responses by gender.

\begin{tabular}{|c|c|c|c|c|c|c|c|c|c|c|}
\hline \multicolumn{2}{|c|}{ Gender } & \multicolumn{10}{|c|}{ Items } \\
\cline { 3 - 12 } \multicolumn{2}{|c|}{} & 1 & 2 & 3 & 4 & 5 & 6 & 7 & 8 & 9 \\
\hline \multirow{3}{*}{ Male } & Mean & 4.92 & 4.84 & 4.82 & 4.78 & 4.76 & 4.62 & 4.42 & 4.16 & 4.34 \\
& SD & .274 & .370 & .388 & .418 & .476 & .530 & .835 & 1.076 & .872 \\
\hline \multirow{3}{*}{ Female } & Mean & 4.81 & 4.78 & 4.59 & 4.67 & 4.74 & 4.63 & 4.26 & 4.00 & 4.04 \\
& SD & .396 & .424 & .501 & .480 & .447 & .565 & .813 & 1.038 & 1.055 \\
\hline \multicolumn{2}{|c|}{$p$-value } & 0.173 & 0.502 & $0.031^{*}$ & 0.282 & 0.738 & 0.862 & 0.271 & 0.405 & 0.215 \\
\hline
\end{tabular}

*Significant at $p<0.05$

The results in Table 6 show that both genders highly perceive that listening is the most important skill compared to other English language skills with men's perception is higher $(M$ $=4.92, \mathrm{SD}=0.274)$ compared to that of women employees $(M=4.81, \mathrm{SD}=0.396)$. Interestingly, in women employees' response, Item 8 ('It will be difficult to get hired in hospitality industry if you can't speak English') has the lowest mean $(M=4.00, \mathrm{SD}=1.038)$. With these results, female employees tend to perceive that hospitality industry requires the employees to be able to speak English, but it is not as significant as those of male employees. In item responses by gender, only the differences in Item 3 are found to be significant. Thus, Hypothesis (1) H0 is accepted (Table 6).

Table 7. Item responses by current job level.

\begin{tabular}{|c|c|c|c|c|c|c|c|c|c|c|}
\hline \multicolumn{2}{|c|}{ Current Job Level } & \multicolumn{10}{|c|}{ Items } \\
\cline { 3 - 12 } & 1 & 2 & 3 & 4 & 5 & 6 & 7 & 8 & 9 \\
\hline \multirow{3}{*}{ Managerial } & Mean & 4.84 & 4.84 & 4.70 & 4.76 & 4.70 & 4.54 & 4.08 & 3.70 & 3.86 \\
& SD & .374 & .374 & .463 & .435 & .520 & .605 & .983 & 1.051 & .918 \\
\hline \multirow{3}{*}{ Supervisor } & Mean & 4.93 & 4.71 & 4.71 & 4.64 & 4.71 & 4.64 & 4.43 & 4.29 & 4.29 \\
& SD & .267 & .469 & .469 & .497 & .469 & .497 & .646 & 1.267 & 1.267 \\
\hline
\end{tabular}


Stefanus Angga B. Prima ${ }^{1}$, Dang Arif Hartono ${ }^{2}$ and Budi Riyanto ${ }^{3}$

J-SHMIC: Journal of English for Academic

Vol 9, No 1, February 2022

\begin{tabular}{|c|c|c|c|c|c|c|c|c|c|c|}
\hline \multirow{2}{*}{ Entry } & Mean & 4.92 & 4.85 & 4.81 & 4.77 & 4.85 & 4.73 & 4.73 & 4.58 & 4.73 \\
& SD & .272 & .368 & .402 & .430 & .368 & .452 & .452 & .703 & .452 \\
\hline \multicolumn{2}{|c|}{$p$-value } & 0.497 & 0.54 & 0.63 & 0.655 & 0.484 & 0.472 & $0.014 *$ & $0.002^{*}$ & $0^{*}$ \\
\hline
\end{tabular}

*Significant at $p<0.05$

On the job level category (Table 7), the results indicate that employees of supervisory level have the highest mean regarding the importance of listening skill $(M=4.93, \mathrm{SD}=0.267)$ compared to employees in managerial and entry level. In this category, the results indicate that most of the employees in managerial level has the lowest mean $(M=3.70, \mathrm{SD}=1.051)$ regarding their perception of how English affects the chance to get hired in hospitality industry (Item 8). In item responses based on the job level, the differences are found to be significant only in Item 7, 8 9, so Hypothesis (2) H0 is accepted (Table 7).

Table 8. Item responses by hotel stars

\begin{tabular}{|c|c|c|c|c|c|c|c|c|c|c|}
\hline \multirow{2}{*}{\multicolumn{2}{|c|}{ Hotel Stars }} & \multicolumn{9}{|c|}{ Items } \\
\hline & & 1 & 2 & 3 & 4 & 5 & 6 & 7 & 8 & 9 \\
\hline \multirow{2}{*}{$\begin{array}{l}\text { Five } \\
\text { Stars } \\
\end{array}$} & Mean & 4.92 & 4.83 & 4.77 & 4.78 & 4.77 & 4.68 & 4.45 & 4.30 & 4.42 \\
\hline & SD & .279 & .376 & .427 & .415 & .465 & .504 & .790 & .979 & .787 \\
\hline \multirow{2}{*}{$\begin{array}{l}\text { Four } \\
\text { Stars }\end{array}$} & Mean & 4.80 & 4.80 & 4.67 & 4.67 & 4.73 & 4.33 & 4.20 & 3.53 & 3.67 \\
\hline & SD & .414 & .414 & .488 & .488 & .458 & .617 & .775 & 1.060 & 1.175 \\
\hline \multirow{2}{*}{$\begin{array}{l}\text { Three } \\
\text { Stars }\end{array}$} & Mean & 4.50 & 4.50 & 4.50 & 4.00 & 4.50 & 5.00 & 3.00 & 2.50 & 3.00 \\
\hline & SD & .707 & .707 & .707 & .000 & .707 & .000 & 1.414 & .707 & 1.414 \\
\hline \multicolumn{2}{|c|}{$p$-value } & 0.108 & 0.48 & 0.542 & $0.037^{*}$ & 0.639 & $0.05^{*}$ & 0.069 & $0.004 *$ & $0.012 *$ \\
\hline
\end{tabular}

*Significant at $p<0.05$

The results in Table 8 show that employees of all hotel stars regard that all skills are important. However, those working at five-star hotels have the highest mean in their perception of the importance of listening skill $(M=4.92, \mathrm{SD}=0.279)$, while those working in three-star hotels has the lowest $(M=4.5, \mathrm{SD}=0.707)$. Furthermore, employees working in the three-star hotels has the lowest mean regarding their perception on Item 8 , which asks whether it will be difficult to get hired in hospitality industry if they cannot speak English $(M=2.50$, $\mathrm{SD}=0.707)$.

Table 8 also shows that employees working in three-star hotels tend to perceive that all English language skills are important, but they tend to perceive that the importance of spoken grammar is far lower than other language skills. Although similar findings are noted across hotel-stars, employees in three-star hotel have the lowest perception of importance regarding this. In this category, the differences are found to be significant only for Item 4, 6, 8, and 9. Therefore, Hypothesis (3) H0 is accepted (Table 8). 
Stefanus Angga B. Primal ${ }^{1}$, Dang Arif Hartono ${ }^{2}$ and Budi Riyanto ${ }^{3}$

J-SHMIC: Journal of English for Academic

Vol 9, No 1, February 2022

Table 9. Item responses by current departments

\begin{tabular}{|c|c|c|c|c|c|c|c|c|c|c|}
\hline \multirow{2}{*}{\multicolumn{2}{|c|}{ Current Departments }} & \multicolumn{9}{|c|}{ Items } \\
\hline & & \multirow{3}{*}{$\begin{array}{c}1 \\
5.00 \\
.000\end{array}$} & \multirow{3}{*}{$\begin{array}{c}2 \\
4.80 \\
.447\end{array}$} & \multirow{3}{*}{$\begin{array}{c}3 \\
5.00 \\
.000\end{array}$} & \multirow{3}{*}{$\begin{array}{c}4 \\
4.60 \\
.548\end{array}$} & \multirow{3}{*}{$\begin{array}{c}5 \\
5.00 \\
.000\end{array}$} & \multirow{3}{*}{$\begin{array}{c}6 \\
4.60 \\
.548\end{array}$} & \multirow{3}{*}{$\begin{array}{c}7 \\
4.80 \\
.447\end{array}$} & \multirow{3}{*}{$\begin{array}{c}8 \\
3.80 \\
1.095\end{array}$} & \multirow{3}{*}{$\begin{array}{c}9 \\
4.20 \\
.447\end{array}$} \\
\hline Others & Mean & & & & & & & & & \\
\hline & SD & & & & & & & & & \\
\hline $\mathrm{F} \& \mathrm{~B}$ & Mean & 4.77 & 4.77 & 4.69 & 4.69 & 4.62 & 4.46 & 4.23 & 4.15 & 4.38 \\
\hline Production & SD & .439 & .439 & .480 & .480 & .506 & .660 & .927 & 1.068 & .870 \\
\hline \multirow[t]{2}{*}{ F\&B Services } & Mean & 4.93 & 4.87 & 4.87 & 4.87 & 4.87 & 4.73 & 4.73 & 4.73 & 4.80 \\
\hline & SD & .258 & .352 & .352 & .352 & .352 & .458 & .458 & .458 & .414 \\
\hline \multirow[t]{2}{*}{ Front Office } & Mean & 5.00 & 5.00 & 5.00 & 5.00 & 5.00 & 5.00 & 5.00 & 4.86 & 4.86 \\
\hline & SD & .000 & .000 & .000 & .000 & .000 & .000 & .000 & .378 & .378 \\
\hline \multirow{2}{*}{ Housekeeping } & Mean & 4.83 & 4.83 & 4.50 & 4.67 & 4.67 & 4.83 & 4.67 & 4.67 & 4.83 \\
\hline & $\mathrm{SD}$ & .408 & .408 & .548 & .516 & .516 & .408 & .516 & .516 & .408 \\
\hline Human & Mean & 4.86 & 4.79 & 4.66 & 4.69 & 4.69 & 4.52 & 3.93 & 3.52 & 3.66 \\
\hline Resources & SD & .351 & .412 & .484 & .471 & .541 & .574 & .923 & 1.153 & 1.078 \\
\hline Sales and & Mean & 5.00 & 4.50 & 4.50 & 4.50 & 4.50 & 4.50 & 4.50 & 4.00 & 3.50 \\
\hline Marketing & SD & .000 & .707 & .707 & .707 & .707 & .707 & .707 & 1.414 & .707 \\
\hline \multicolumn{2}{|c|}{$p$-value } & 0.667 & 0.749 & 0.174 & 0.487 & 0.289 & 0.286 & $0.003 *$ & $0.003 *$ & $0^{*}$ \\
\hline
\end{tabular}

*Significant at $p<0.05$

Generally, all employees from all departments consider all skills as important with little differences between departments. Interestingly, the results indicate that employees from Front Office department have the highest mean regarding the importance of listening skill in their job $(M=5, \mathrm{SD}=.000)$, followed by those working in Food and Beverage Services $(M=4.93$, $\mathrm{SD}=0.258)$. On the contrary, those working in Food and Beverage production, such as pastry and kitchen, has the lowest mean $(M=4.23, \mathrm{SD}=0.927)$ regarding their perception of spoken grammar skill (Item 7). Then, regarding their attitudes towards other factors related to English language skill, those working in Sales and Marketing have the lowest mean in Item 8 ('It will be difficult to get promoted in hospitality industry if you can't speak English'). The differences are found to be significant only for Item 7, 8, and 9. Thus, Hypothesis (4) H0 is accepted (Table 9).

\section{DISCUSSION}

The findings show that to work in hospitality and tourism industry, employees perceive that listening is the most important skill, followed by speaking, reading, writing, vocabulary, written grammar, then spoken grammar. The necessity to use accurate grammar during speaking is considered the least important for the employees. In this context, where English is used between non-natives, speakers will adapt each other's grammar and pragmatics competence to ensure intelligibility (Canagarajah, 2007; McKay, 2018). Thus, creating materials that focus on oral language competence is important. List of high frequency words 
or expressions in the tourism industry may be used to create materials to improve employees' candidates or students currently studying in hospitality and tourism major (Bury, 2014). Nevertheless, curriculum and material designers need to assess how far they will teach accuracy in speaking context.

As employees tend to perceive that spoken grammar is not as significant as other language skills, it is important to consider teaching pragmatic competence for these employees or employees' candidates considering English as lingua franca (ELF). Pullin (2015) argues that factors contributing effective communication among speakers of ELF should be taken. She further mentions that native-like English competence is not always necessary to be made as a model. This poses challenges but also opportunities for teachers or curriculum developers in English for Tourism or Hospitality, to consider skills of clarification and meaning negotiation while speaking in English.

The findings also support the previous research which indicate that English language listening and speaking skills are the most important communicative skills in hospitality and tourism industry although sometimes not being given enough attention (Bury \& Oka, 2017; Ghany \& Latif, 2012; Yasmin et al., 2016). Other similar studies, however, have a slightly different result (Kaharuddin et al., 2019; Prachanant, 2012), in which it is found that speaking as the most important among tourism employees, followed by listening, reading, and writing.

It is also imperative to note that employees working in Front Office unanimously consider that all skills as highly important. This finding is similar to several previous studies, in which listening and speaking play vital role in completing the tasks of hotel employees, especially front office agents (Datu et al., 2020; Davies, 2000; Yuit, 2002). Further, speaking and listening are commonly considered as inseparable skills, especially in a job that requires frequent oral communication with foreigners and as important as front office agents.

Front Office participants consider written and spoken grammar as equally important with listening, speaking, reading and vocabulary. This shows how front office agents utilize all language skills to deal with foreign guests because the nature of their work ranges not only in the form of oral communication, but also written communication. Front office is the most noticeable part in hotel businesses, so communication which ensures immediate guest satisfaction in both spoken and written language is necessary (Bardi, 2007, as cited in Kardijan (2017).

The significant difference of Item 8 and 9 in the category of job level shows that the hotel employees in managerial level perceive that English language competence is not a dominant factor in getting hired or getting promoted. This is significantly different from the perception of employees in the entry level who mostly agree that English language skill affects their chance to get hired or promoted in hospitality industry. The findings among employees of supervisory and entry level support a study in Korea and one in Indonesia which indicate that English skills play a vital role in getting hired or promoted (Park, 2011; Wulyani et al., 2021). Conversely, employees working in non-five-star hotels tend to perceive that English language skill does not affect the opportunity to get hired or promoted in hospitality and tourism industry. This remarkable difference between hotel stars indicates that most employees in higher hotel stars are required to master English language. The Regulation of the Minister of Tourism and Creative Economy of the Republic of Indonesia stipulates that minimum $75 \%$ of the total employees in a five-star hotel should be able to use English actively (Kemenparekraf, 2013). 
The results of the investigation in this study contributes to the study of needs analysis in the scope of curriculum and material design in English for Specific Purposes especially in the field of English for Tourism and Hospitality. However, several limitations of the study still need further exploration in the future research. One is that the result is not generalizable and only focuses on Jakarta and Bali. Therefore, future studies may bring other major Indonesian cities. Other than that, the participants of the study were strongly skewed to employees of fivestar hotels, due to the research time limitation and access. Thus, future studies need to include more samples from non-five-star hotels.

\section{CONCLUSION}

Although several items in the participant variables were found to be statistically significant, Hypotheses (1) H0, (2) H0, (3) H0 and (4) H0 are all accepted. This indicates that there are no significant differences of employees' perception from different group categories observed in this study (gender, job level, hotel stars, current departments). Employees generally perceive that listening and speaking as the most important skills, while spoken grammar as the least important skills.

Looking at the results, it is imperative for teachers and curriculum designers to consider how spoken grammar is perceived as the least important among other language skills. Currently some classes still emphasize quite heavy attention on grammatical accuracy during speaking class and assessment. Although accuracy is necessary to avoid misunderstanding and to improve the ability to convey complex messages, teachers or instructional designers must delve into more alternatives on how to assess the students' ability between those of non-native speakers in tourism and hospitality industry. English as International Language should be a matter of importance between non-native speakers working in professional setting.

Apart from that, English lecturers and teachers in Indonesia who are responsible to teach English classes for hospitality and tourism need to pay attention on how different departments require different emphasis of English language skills. It is much more time and resource costly to customize English classes for specific needs but ensuring that learners can learn efficiently and appropriate to the target 'discourse community' should be the ultimate efforts of all institutions.

\section{REFERENCES}

Brown, J. D. (2015). Why bother learning advanced quantitative methods in L2? In L. Plonsky (Eds.), Advancing quantitative methods in second language research (pp. 9-20). New York: Routledge.

Bury, J. (2014). Developing texts for an English for tourism course: The effect of using taskcycling, spaced retrieval and high-frequency words on students' self-perceptions of ability and levels of confidence, The Journal of Teaching English for Specific and Academic Purposes, 2(2), 181-194. Retrieved from http://espeap.junis.ni.ac.rs/index.php/espeap/article/view/106

Bury, J., \& Oka, T. (2017). Undergraduate students' perceptions of the importance of English in the tourism and hospitality industry. Journal of Teaching in Travel and Tourism, 17(3), 173-188. https://doi.org/10.1080/15313220.2017.1331781 
Canagarajah, S. (2007). Lingua franca English, multilingual communities, and language acquisition. The Modern Language Journal, 91(Focus Issue), 923-939.

Cao Thanh, N. (2015). The differences between spoken and written grammar in English, in comparison with Vietnamese. GiST Education and Learning Research Journal, 11(11), 138-153. https://doi.org/10.26817/16925777.291

Datu, Y. A., Limantoro, S. W., Soelistiyowati, E., Hardjanto D., T., \& Fuadi, Y. (2020). ESP test for hotel front office: Is it a need? PEOPLE: International Journal of Social, 6(1), 690-704. https://doi.org/https://doi.org/10.20319/pijss.2020.61.690704

Davies, J. (2000). A study of language skills in the leisure and tourism industry. Language Learning Journal, 21(1), 66-71. https://doi.org/10.1080/09571730085200131

Dudley-Evans, T., \& St John, M. (1998). Developments in ESP: A multi-disciplinary approach. Cambridge: Cambridge University Press.

Ghany, S. Y. A., \& Latif, M. M. A. (2012). English language preparation of tourism and hospitality undergraduates in Egypt: Does it meet their future workplace requirements? Journal of Hospitality, Leisure, Sport and Tourism Education, 11(2), 93-100. https://doi.org/10.1016/j.jhlste.2012.05.001

Hutchinson, T., \& Waters, A. (1987). English for specific purposes: A learning-centred approach. Cambridge: Cambridge University Press. https://doi.org/doi:10.1017/CBO9780511733031

Kaharuddin, Hikmawati, \& Burhanuddin, A. (2019). Needs analysis on English for vocational purpose for students of hospitality department. The Second Annual International Conference on Language and Literature, KnE Social Sciences, 2019, 344-387. https://doi.org/10.18502/kss.v3i19.4869

Kardijan, D. (2017). The gap between learning needs and its implementation in English for hospitality specific purposes program. English Review: Journal of English Education, 6(1), 125. https://doi.org/10.25134/erjee.v6i1.779

Kemenparekraf. (2021, February 8). Statistik kunjungan wisatawan mancanegara 2020. Kemenparekraf. $\quad$ Retrieved February 21, 2022, from https://www.kemenparekraf.go.id/statistik-wisatawan-mancanegara/StatistikKunjungan-Wisatawan-Mancanegara-2020

Kemenparekraf, I. (2013). Peraturan Menteri Pariwisata and Ekonomi Kreatif No. 53 tahun 2013. Peraturan Menteri Pariwisata Dan Ekonomi Kreatif Republik Indonesia, 227. Retrieved from https://www.equalityindonesia.com/downloads/peraturan/PERMEN Parekraf_No_53-2013 SU HOTEL.pdf

Long, M. H. (Ed.). (2005). Second language needs analysis. Cambridge University Press. https://doi.org/10.1017/CBO9780511667299

McKay, S. L. (2018). English As an International Language: What It Is and What It Means For Pedagogy. RELC Journal, 49(1), 9-23. https://doi.org/10.1177/0033688217738817

Park, J. S. (2011). The promise of English : linguistic capital and the neoliberal worker in the South Korean job market. International Journal of Bilingual Education and Bilingualism, 14(4), 443-445. https://doi.org/10.1080/13670050.2011.573067 
Prachanant, N. (2012). Needs analysis on English language use in tourism Industry. Procedia - Social and Behavioral Sciences, 66, 117-125. https://doi.org/10.1016/j.sbspro.2012.11.253

Pullin P. (2015) The application of English as a lingua franca (ELF) research findings to the teaching of pragmatic competence. In: Beeching K., Woodfield H. (Eds.), Researching sociopragmatic variability. Palgrave Macmillan, London. https://doi.org/10.1057/9781137373953_12

Putri, N. E., Kher, D. F., \& Rani, Y. A. (2018). English for specific purposes: English language needs in hospitality and travel Industry, International Journal of Multidisciplinary of Higher Education 1(1), 1-17. Retrieved from http://ijmurhica.ppj.unp.ac.id/index.php/ijmurhica/article/view/8

Terauchi, H. (2019). ESP today. In H. Terauchi, J. Noguchi, \& A. Tajino (Eds.), Towards a new paradigm for English language teaching: English for specific purposes in Asia and beyond. New York: Routledge. https://doi.org/10.4324/9780429423963

Wulyani, A. N., Saukah, A., Syahid, A., Utami, P., Susilo, S., (2021). Understanding English language teachers' views of teacher research. TEFLIN Journal, 32(2), 362-388.

Yasmin, M., Sarkar, M., \& Sohail, A. (2016). Exploring English language needs in the hotel industry in Pakistan: An evaluation of existing teaching material. Journal of Hospitality and Tourism Education, 28(4), 202-213. https://doi.org/10.1080/10963758.2016.1226846

Chan, Mei-Yuit (2002). English language communication training needs of front office assistants of hotels in Kuala Lumpur. In Jayakaran Mukundan, Arshad Abd Samad \& Teh Chee Seng (Eds.), Readings in English Language Teaching (ELT): Selected Papers from the Millennium MICELT (pp. 35 - 44). Serdang, Malaysia: Penerbit Universiti Putra Malaysia.

Zahedpisheh, N., B Abu bakar, Z., \& Saffari, N. (2017). English for Tourism and Hospitality Purposes (ETP). English Language Teaching, 10(9), 86-94. https://doi.org/10.5539/elt.v10n9p86

\section{APPENDIX}

List of statements and questions in the questionnaire items (English version).

\section{QUESTIONNAIRE ITEMS:}

1. Good listening skills in English are very important in the hospitality and tourism industry.

(5) Strongly agree

(4) Agree

(3) Neither agree nor disagree

(2) Disagree

(1) Strongly disagree

2. Good speaking skills in English are very important in the hospitality and tourism industry.

(5) Strongly agree 
Stefanus Angga B. Prima ${ }^{1}$, Dang Arif Hartono ${ }^{2}$ and Budi Riyanto ${ }^{3}$

J-SHMIC: Journal of English for Academic

Vol 9, No 1, February 2022
(4) Agree
(3) Neither agree nor disagree
(2) Disagree
(1) Strongly disagree

3. Good reading skills in English are very important in the hospitality and tourism industry.
(5) Strongly agree
(4) Agree
(3) Neither agree nor disagree
(2) Disagree
(1) Strongly disagree

4. Good writing skills in English are very important in the hospitality and tourism industry.

(5) Strongly agree

(4) Agree

(3) Neither agree nor disagree

(2) Disagree

(1) Strongly disagree

5. Knowing a lot of English vocabulary related to the hotel and tourism industry is very important.

(5) Strongly agree

(4) Agree

(3) Neither agree nor disagree

(2) Disagree

(1) Strongly disagree

6. When writing or typing in English, it is important for me to use proper grammar.
(5) Strongly agree
(4) Agree
(3) Neither agree nor disagree
(2) Disagree
(1) Strongly disagree

7. When speaking in English, it is important for me to use proper grammar.
(5) Strongly agree
(4) Agree
(3) Neither agree nor disagree
(2) Disagree
(1) Strongly disagree

8. Without good English skills, it will be very difficult for job seekers to find work in the hospitality and tourism industry.

(5) Strongly agree

(4) Agree

(3) Neither agree nor disagree 
Stefanus Angga B. Prima ${ }^{1}$, Dang Arif Hartono ${ }^{2}$ and Budi Riyanto ${ }^{3}$

J-SHMIC: Journal of English for Academic

Vol 9, No 1, February 2022

(2) Disagree

(1) Strongly disagree

9. If I don't have good English skills, it will be difficult for me to get a promotion.

(5) Strongly agree

(4) Agree

(3) Neither agree nor disagree

(2) Disagree

(1) Strongly disagree

DEMOGRAPHIC QUESTIONS:

10. Are you a male or female?

11. How old are you?

12. What is your last education level?

13. What is your current job level?

14. In which hotel star are you currently working?

15. In which department are you currently working? 